\title{
MEDIEVAL NORWEGIAN WOODEN (STAVE) CHURCHES: BUILT HERITAGE AND PLACES OF MEMORY
}

Kata SZILÁGYi ${ }^{1}$ - ANETTE SAND-ERIKSEN ${ }^{2}$

Hungarian Archaeology Vol. 10 (2021), Issue 1, pp. 30-40. https://doi.org/10.36338/ha.2021.1.5

This paper focuses on the Norwegian medieval religious buildings called stave churches. The word stave (meaning 'post, pole' in Norwegian) derives from the buildings' post and lintel construction, giving the churches their characteristic style. The structures display a highly developed tradition of wooden Christian buildings, which during the Middle Ages (1050-1500) where the most common in Norway, their number can be estimated at around a thousand. There were probably at least as widespread in other areas (e.g. on the territory of present-day Germany and Russia), but they did not remain in such a large number from the early period. However, the number have declined dramatically, and today only 28 are preserved. The article aims to expand the knowledge of the unique and irreplaceable wooden architecture of the stave churches. Although we consider the wooden churches to be one of the characteristics of Scandinavia traditionally, they mix and carry the influences of other cultures and countries. The heritage and memorial role of wooden churches, as well as the motif of the combination of different architectural and religious elements, represent an interesting comparison to similar phenomena in the Carpathian Basin. Transylvania and especially the Maramureş region are also famous for their wooden churches and the rich carved and painted iconostasis.

Keywords: North-Europe, Norway, Middle Age, Stave church, wooden architecture, Nordic style, cultural memory, cultural heritage

\section{WHAT ARE STAVE CHURCHES AND WHY ARE THEY SO SPECIAL?}

In the medieval period, large stone or brick churches where build all over Europe. During this period, a similar building technique was developed in Norway. There was one big difference, however - the main material. While stone and masonry where the preferred material in large parts of Europe, Norway had an abundance of timber. As a result, stave churches (in Norwegian: stavkirke) became the dominant type of religious building during the medieval period in Norway (1050-1500) (Fig. 1). With regard to the Carpathian Basin, these churches provide a particularly interesting and relevant point of comparison, as Christianization in Norway and the Kingdom of Hungary took place at the same time and, in many respects, show similarities. The Old Norse religious/belief system, like the Hungarian pagan faith, was constantly transformed and became part of the Christian religion, which was politically accepted and clearly supported in order to consolidate power (BEREND et al. 2007, 319-320). Numerous data suggest that a large number of wooden churches were built after the incorporation of Christianity in almost

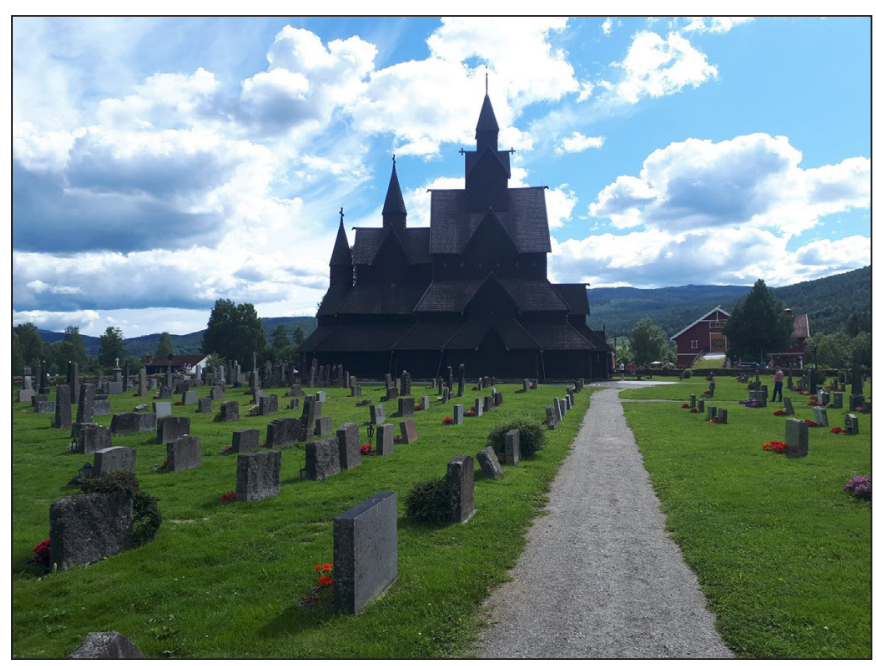

Fig. 1. The Heddal stave church in Notodden (Telemark, Norway) (photo by Kata Szilágyi)

\footnotetext{
1 University of Oslo, Faculty of Humanities, Department of Archaeology, Conservation and History, Oslo, Norway. E-mail: szil.szvetlana@gmail.com

2 University of Oslo, Museum of Cultural History, Oslo, Norway. E-mail: anette.sand-eriksen@khm.uio.no
} 
all areas, including Hungary, but not any built remains has survived. This is also why it is particularly interesting what kind, size and nature of stave churches may have been built during this early period.

These unique wooden structures are built around a timber framing of poles (in Old Norwegian: stafr, in Modern Norwegian: stav), an element so characteristic that it has led to the naming of the medieval church type. In this frame, the vertical poles (or pillars) stand on reclining sleepers or sill logs, holding up the horizontal roof bearing poles. This construction method allows for large space between the elements, thus creating big open spaces and forming the characteristic verticality of the building. This method and architectural expression contrasted the other horizontal block or log buildings that existed in Norway during the Middle Ages.

At its most, there were between 750-1300 stave churches in Norway (JENSENIUS 2000), a high number compared to the 271 concurrent stone churches. The large difference where of course due to the abundance of timber, but where also a direct result of old Norwegian laws ruling stave churches as the standard church type (Hauglid 1970; AnKer 1997, 2005). According to Norway's oldest written laws and Old Norwegian Homily Book (Gammelnorsk homiliebok, Fig. 2), the consecration of the church was valid as long as the four corner posts were standing (ANKER 1997, 182-184; BAMPI et al. 2018). In this book, one of the sermon called as the 'stave church sermon', which is a theological interpretation of the building elements (source of terminology and technique). It is dated to the period around 1100 (Hoftun 2008).

The traditional Scandinavian wooden architecture, the architectural tradition and method of the buildings extended beyond Scandinavia, and it also brought traces from other cultures and countries to Norway. One example is the Urnes Stave Church, with components from Celtic art, Viking traditions and Romanesque stone habit, this outstanding example of a stave church was placed on the UNESCO World Heritage List in 1979, it is important to highlight the importance of this, as at that time only some monuments were added to the list. An important measure to secure and preserve the unique and irreplaceable architectural tradition of the stave churches, which have declined so dramatically in number, and today there are only 28 stave churches preserved (Christie 1981, 139-203; Jensenius 2000, 7-10) (Table 1, Fig. 3). Similarly, the wooden churches in Maramureș have been part of the UNESCO World Heritage List and they have been protected heritage sites since 1999. In addition, in the Carpathian region, the wooden churches in Slovakia and in Southern Małopolska are also included in the World Heritage List.

\begin{tabular}{|c|l|l|l|l|}
\hline Site ID & Site name & Municipality & County & Date \\
\hline 1 & Borgund & Lærdal & Sogn og Fjordane & early 12th century \\
\hline 2 & Eidsborg & Tokke & Telemark & 13 th century \\
\hline 3 & Flesberg & Flesberg & Buskerud & c 1150-1200 \\
\hline 4 & Garmo & Lom/Lillehammer & Oppland & c 1150-1200 \\
\hline 5 & Gol & Gol & Buskerud & early 13th century \\
\hline 6 & Grip & Kristiansund & Møre og Romsdal & 14-15th century \\
\hline 7 & Haltdalen & Holtålen & Sør-Trøndelag & late 12th century \\
\hline 8 & Hedalen & Sør-Aurdal & Oppland & late 12th century \\
\hline 9 & Heddal & Notodden & Telemark & early 13th century \\
\hline 10 & Hegge & Øystre Slidre & Oppland & early 13th century \\
\hline 11 & Hopperstad & Vik & Sogn og Fjordane & early 12th century \\
\hline 12 & Høre & Oppland & Oppland & late 12th century \\
\hline 13 & Høyjord & Andebu & Vestfold & late 12th century \\
\hline 14 & Kaupanger & Sogndal & Sogn og Fjordane & late 12th century \\
\hline 15 & Kvernes & Averøy & Møre og Romsdal & late 14th century* \\
\hline 16 & Lom & Lom & Oppland & late 12th century \\
\hline 17 & Lomen & Vestre Slidre & Oppland & late 12th century \\
\hline
\end{tabular}


Kata Szilágyi-Anette Sand-Eriksen • Medieval Norwegian Wooden (Stave) Churches

\begin{tabular}{|l|l|l|l|l|}
\hline 18 & Nore & Nore og Uvdal & Buskerud & late 12th century \\
\hline 19 & Øye & Vang & Oppland & late 12th century \\
\hline 20 & Reinli & Sør-Aurdal & Oppland & late 12th century \\
\hline 21 & Ringebu & Ringebu & Oppland & $12-13$ th century \\
\hline 22 & Rødven & Rauma & Møre og Romsdal & $12-13$ th century \\
\hline 23 & Røldal & Odda & Hordaland & $12-13$ th century \\
\hline 24 & Rollag & Rollag & Buskerud & late 12th century \\
\hline 25 & Torpo & All & Buskerud & late 12th century \\
\hline 26 & Undredal & Aurland & Sogn og Fjordane & late 12th century \\
\hline 27 & Urnes & Luster & Sogn og Fjordane & early 12th century \\
\hline 28 & Uvdal & Nore og Uvdal & Buskerud & late 12th century \\
\hline
\end{tabular}

Table 1. Overview table with key data of the preserved stave churches in Norway sources of the data: TSCHUDI-MADSEN 2019; STAVKYRKJEEIGARFORUM 2020; JENSENIUS 2017; WIKIPEDIA 2020. *Based on the new dating: 1631-1633

\section{HISTORICAL BACKGROUND}

The stave churches appeared in Scandinavia at the beginning of the 11th century, almost at the same time as when Christianity were established as the official religion in Norway, after a several century long transitional period. The Christian impulses came from England and Germany, where especially Ansgar (the Archbishop of Hamburg-Bremen, 796-865) was a decisive figure, but driven forward by the Norwegian kings Håkon I (920-961), Olav I (963-1000) and the later canonized Olav II (995-1030) (AHrEns 1982, 37-40; ANKER 1997, 202-204) (Fig. 2). Although stave churches were built centuries after Norway were Christianized and syncretism was not tolerated, many Old Norse religious elements are used to decorate and adorn the churches (e.g. dragon heads and Old Norse symbols in carvings). This mixture of the old Norse and the new Christian religion existed alongside each other for two hundred years. Here, the Norse religious elements were accepted as adornments on the churches with the means of reshaping and translating the old religion into Christianity.

The stave churches were particularly common in lower populated regions and villages, mostly located in high valleys, woodland areas, and along the shoreline of fjords. In particular, between 1600 and 1700 many wooden churches have been remodelled or structurally rebuilt by other techniques. One

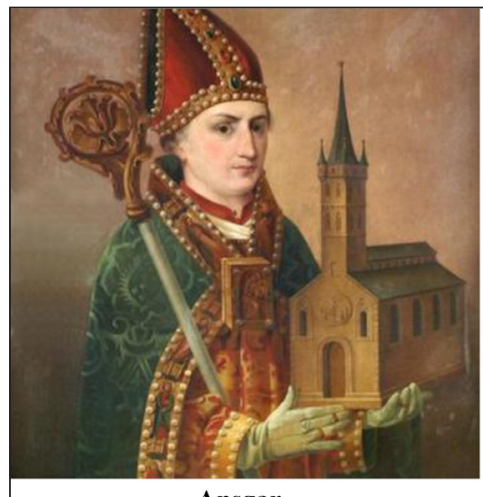

Ansgar

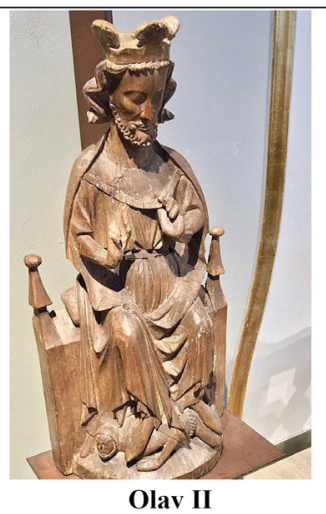

Olav II

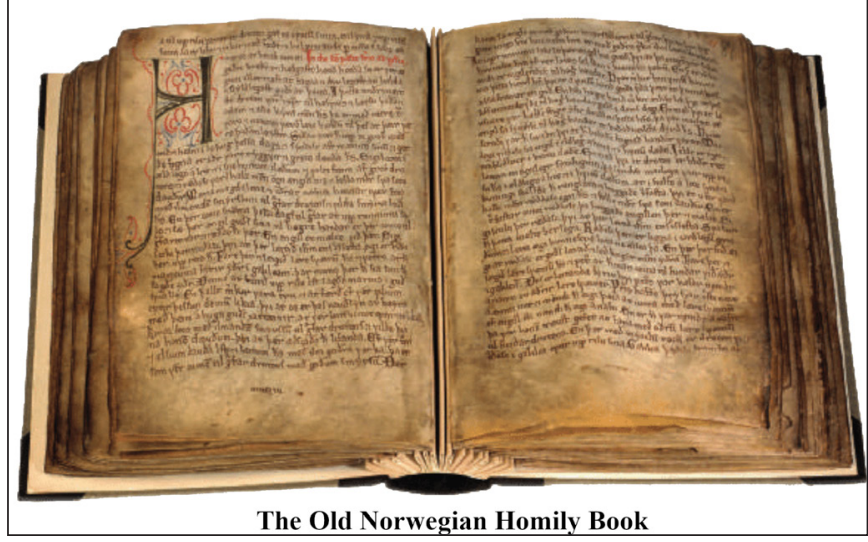

Fig. 2. Ansgar's portrait in the St. Trinitatis Church (Hamburg, 1457), the wooden statue of Olav II

(Kulturhistorisk Museum, Oslo, 1260-1280), and the Old Norwegian Homoly Book (ca. 1200) (image source: Wikimedia Commons; BAMPI et al. 2018, 55) example is the Flesberg Stave Church, converted from a single nave stave church to having a cruciform plan in 1735. The reason for such remodelling, and especially the dismantle of stave churches, were partly because the old churches had become too small for the parish, but also because so many of the buildings were in poor conditions. In addition to these human interventions, several churches also were damaged by natural catastrophes (e.g. fire, storm, avalanche, 


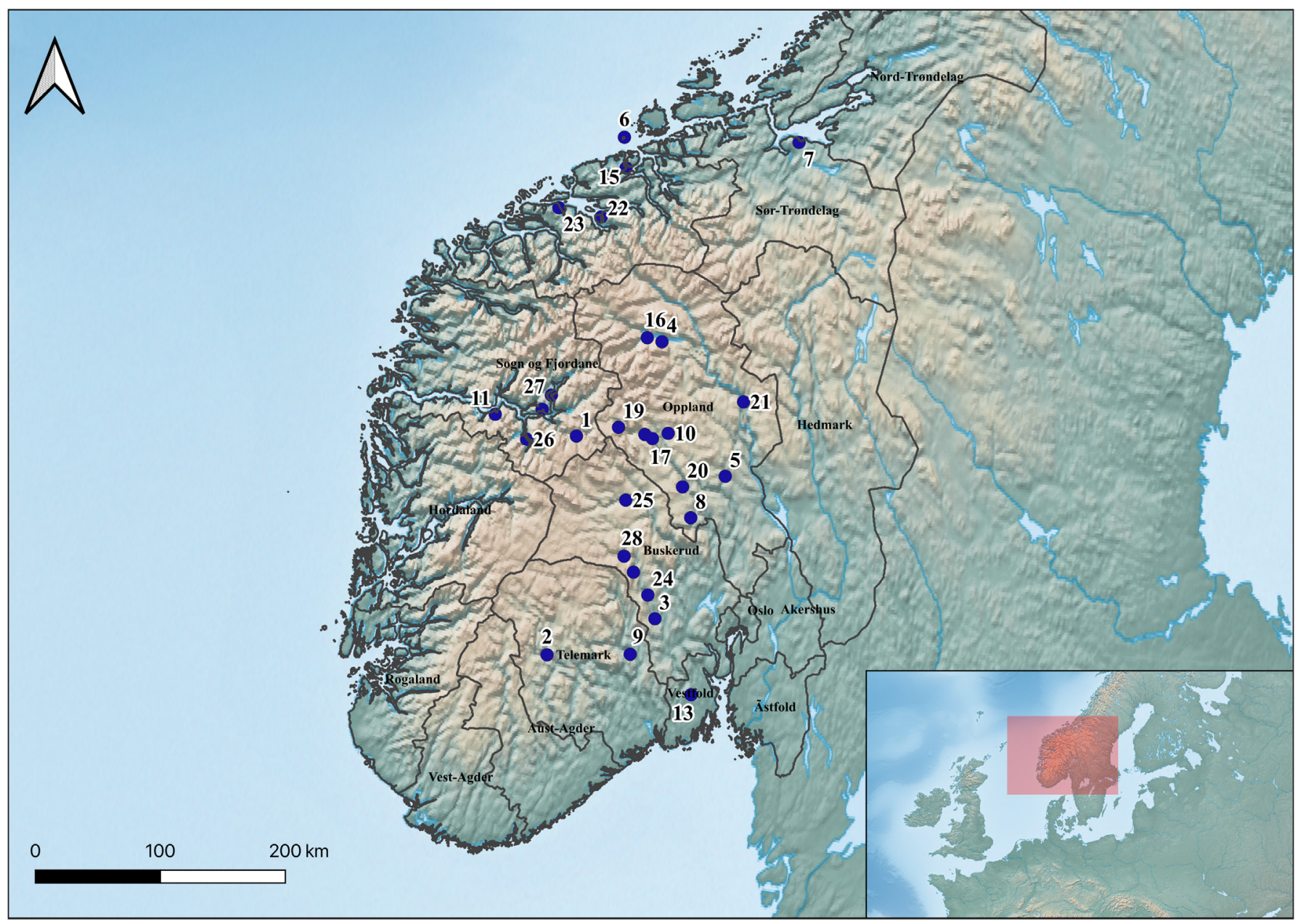

Fig. 3. Map of the preserved stave churches in Norway (created by Kata Szilágyi)

etc.). In 1650, the known number of stave churches was around 270, and within the next centenary, 136 of them disappeared. By 1800, there were only 95 stave churches left in Norway, and the number fell to 32 by 1885 (ANKER 1997, 15). However, during this latter period, the unique architecture of the stave churches was rediscovered. Beginning with Johannes Flintoe's drawings and description of Heddal Stave Church (1834), which was the first stave church in a scholarly publication. His drawing, dated to 1819 , is the first known architectural drawing of a stave church (Fig. 4). The growing interest in stave churches during the 19th century culminated in Lorentz Dietrichson's (1834-1917, Norwegian poet and historian of art and literature) publication about stave churches in 1892, titled The Norwegian Wooden Churches (De norske stavkirker; ANKER 1997, 184-185).

\section{FOUNDATION ENGINEERING AND ARCHITECTURE}

Stave churches were always built on square-shaped wooden frames, situated on a stone base, mostly to protect the wooden frame from water damage. The wooden frame consists of vertical columns (staves), which also form the entire roof structure. The sim-

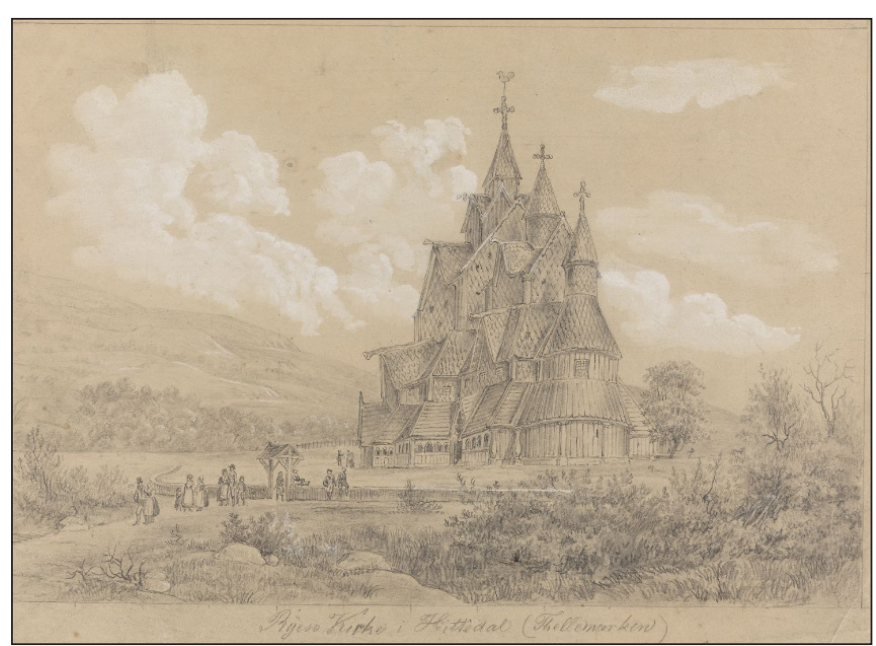

Fig. 4. Johannes Flintoe: Heddal stavekirke. Pencil and gouache on paper, 1848. The National Museum of Art, Oslo, Norway (source: Nasjonalmuseet Oslo 2 https:// nasjonalmuseet.no/samlingen/objekt/NG.K H.B.06314) 
plest, and probably oldest form is called the simple hall church (ANKER 1997; 2005). Here the poles are located in the walls of the frame, leaving a large free space within the church. This type of construction has a single nave and staves only at the corners of the outer wall. The walls consist of vertical planks inserted into the groove of the horizontal beams of the frame - this is called zsilipfal (movable wall) in Hungarian folk architecture. In more complex churches, a gallery (in Norwegian: svalgang) was constructed outside, shaped like another, onion-like shell. The gallery had the constructional benefit of both protecting the church from the weather and providing support for the multi-levelled roof, while also functioning as a meeting place before and after the service. In the middle of this basic framework, horizontal beams were inserted at the same height as the beams of the frame used to finish the walls (BJERKNES \& LidÉn 1975, 55-90; JENSENIUS 1988, 11, 19, 23-25). Above these beams in the basic frame, crosses of St. Andrew were in some cases used as crossbars. In this case, the uppermost

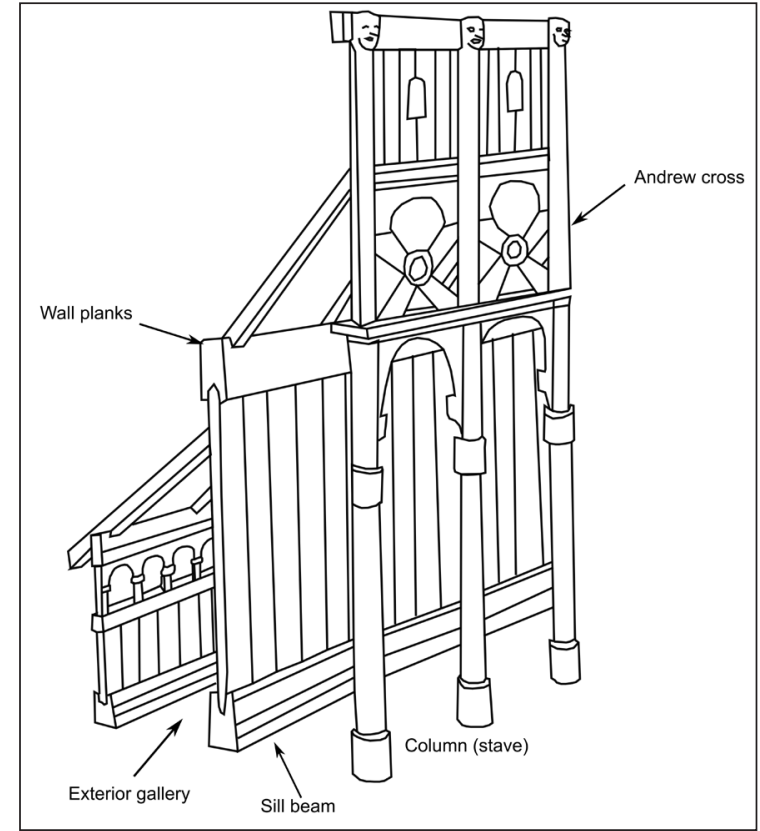

Fig. 5. The schematic framework of the stave church architecture (drawing by Kata Szilágyi)

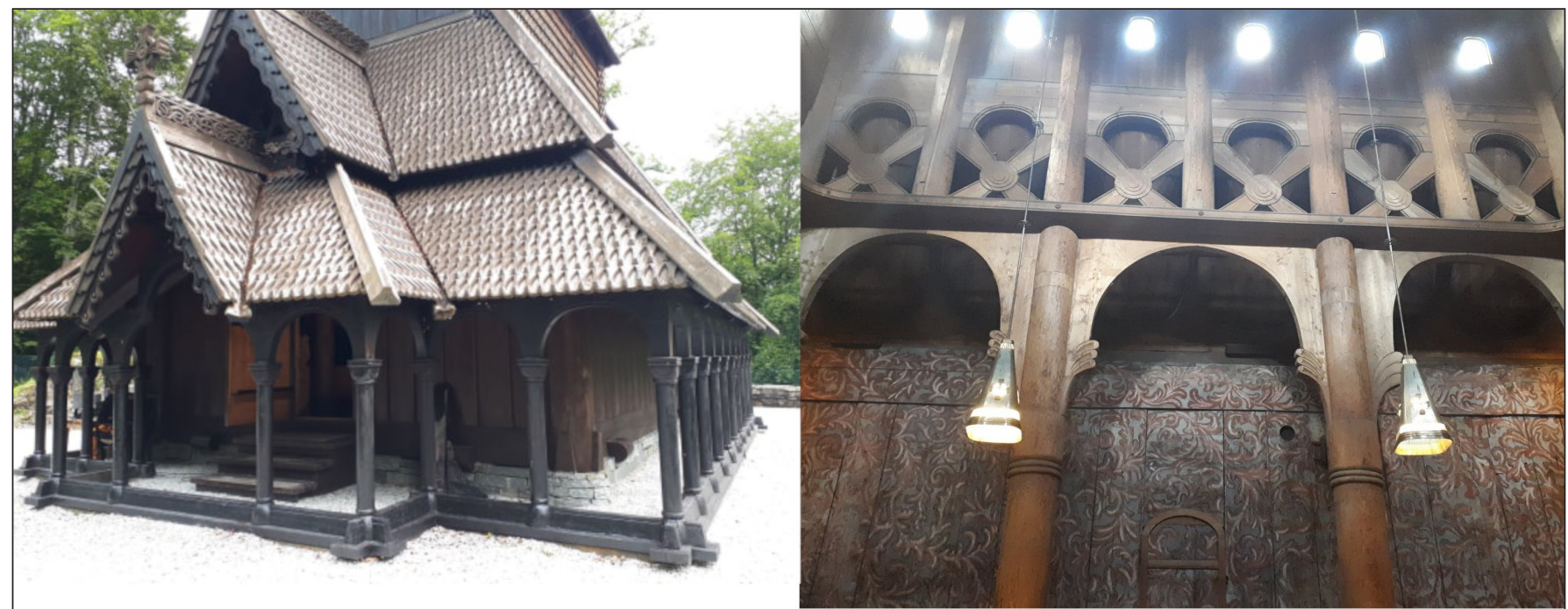

1

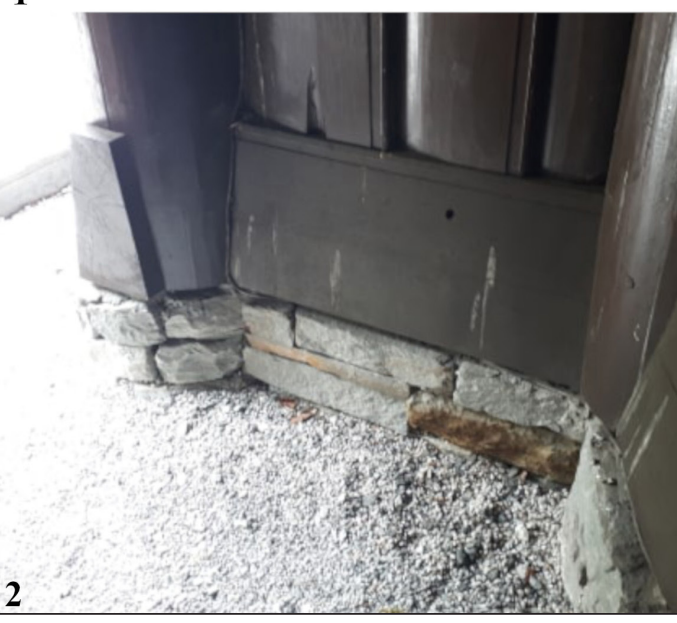

3

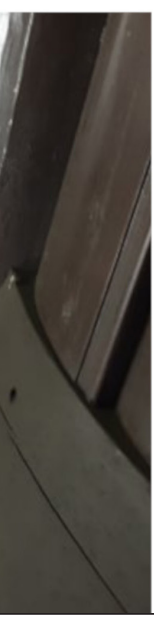

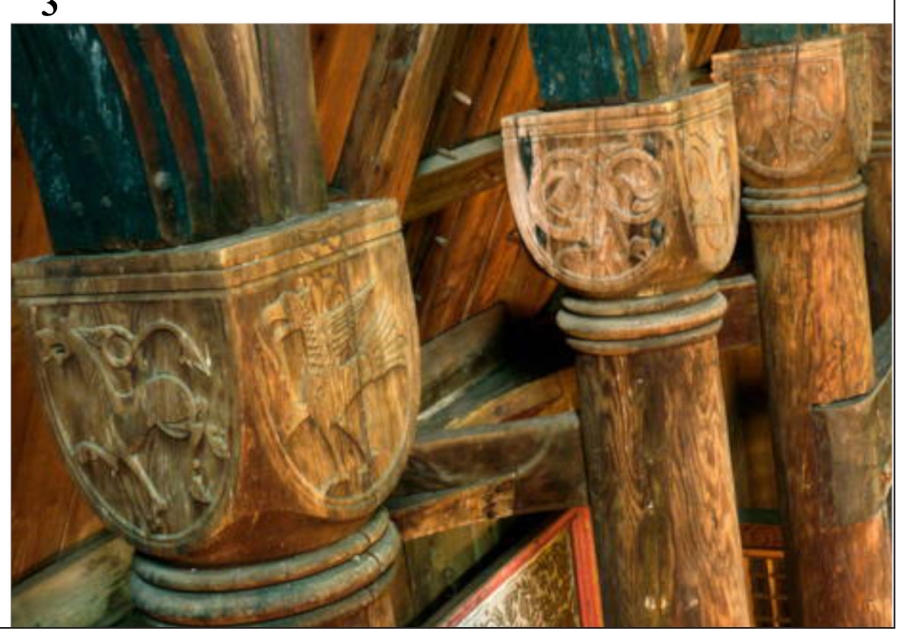

Fig. 6. Examples for the stone base, the decorated poles and the St. Andrew cross. 1-2. Fantoft (photo by Kata Szilágyi),

3. Heddal (photo by Kata Szilágyi), 4. Urnes (photo@OUR PLACE The World Heritage Collection, source: Unesco, https://whc.unesco.org/en/documents/130610) 
Kata Szilágyi-Anette Sand-Eriksen • Medieval Norwegian Wooden (Stave) Churches

part of the base frame would be open from the outside above the columns, so in order to avoid this, like the lower walls, this part was also covered with planks (CHristie 1981, 228; HoHLER 1981, 264; VALEBroKK 1993) (Figs. 5-6).

\section{ROOFS}

The single nave churches have a simple gable roof, while the more complex churches have steep roofs with levels or steps, creating the iconic (Nordic) style of the stave churches. This steep roofing construction is called a pent roof, and it is followed by gable roofs. The more complex variants often have conical or pyramidal towers on top of the roof, which also can consist of several stages. This overall gradual reduction of the roofs makes the buildings appear larger than they actually are, a concept called 'forced perspective technique' (ANKER 1997, 190-195). In the 19th century, Lorentz Dietrichson compared the roof construction with another signature Norwegian wooden structure, the Viking ships (ANKER 1997, 184-185). He argued that static considerations of contemporary shipbuilding were used in the construction of stave churches. However, this theory is disputed, and today some scholars (e.g. AHrens 2001) see a similarity in the construction of stave church roofs with other contemporary West-European roof constructions - such as the masonry Garda church in Löjsta in Sweden, several Danish Viking Age buildings, i.e. the circular

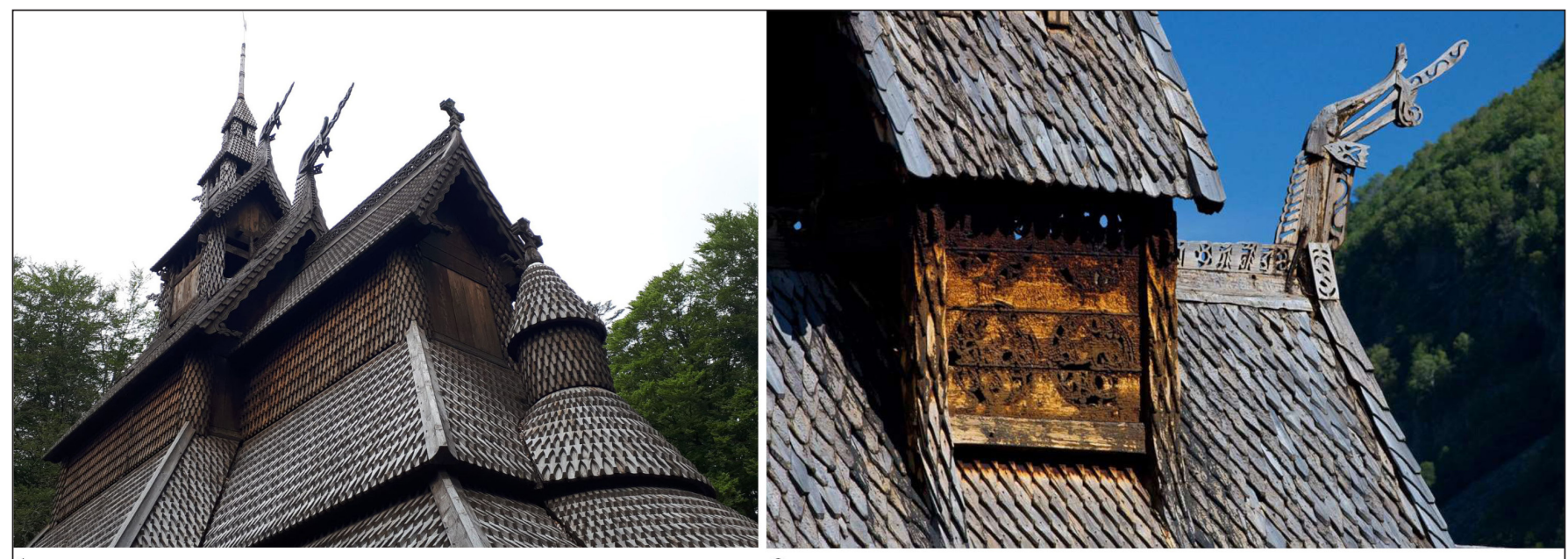

1

2

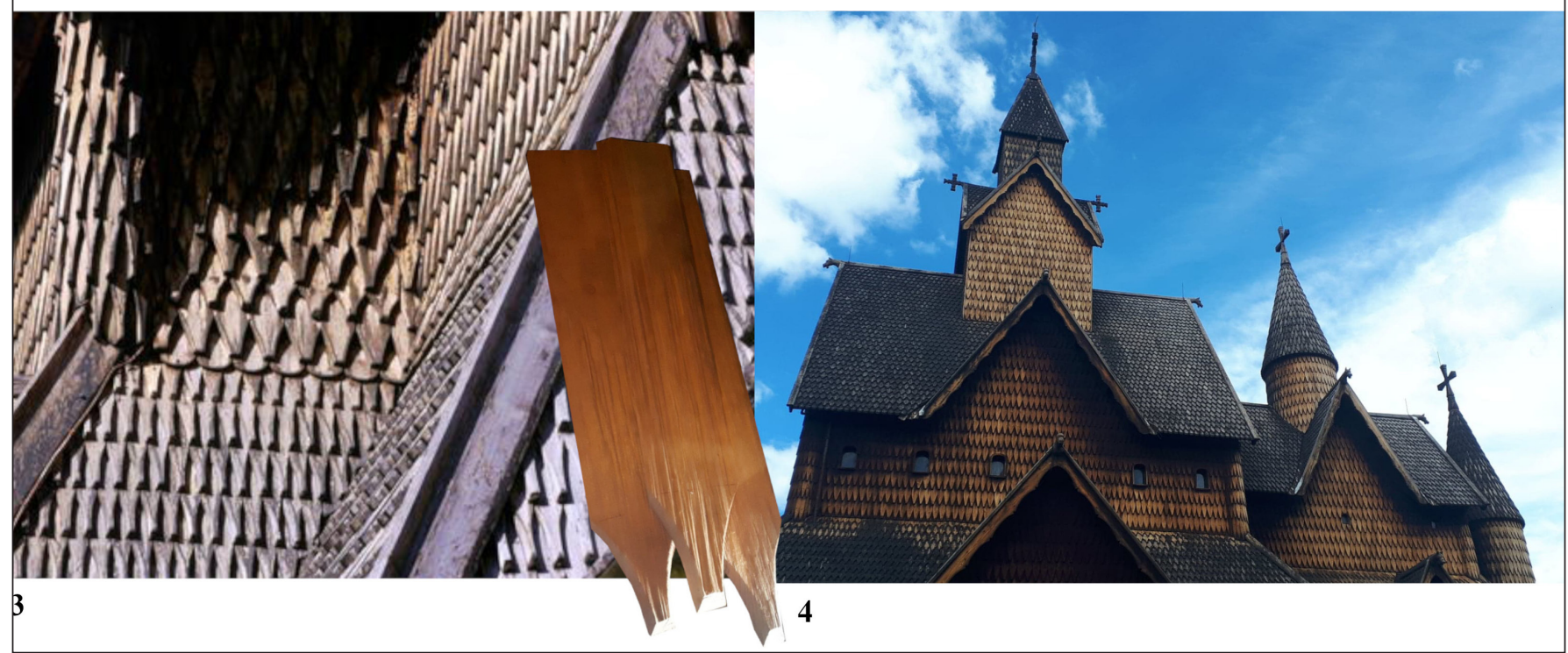

Fig. 7. Roof tiles, motives from the Norse religion and Christian ornaments on the pediments. 1. Fantoft (photo by Kata Szilágyi), 2. Borgund (source: www.visitnorway.com), 3. Urnes (photo@OUR PLACE The World Heritage Collection, source: Unesco, https://whc.unesco.org/en/documents/130610), 4. Heddal (photo by Kata Szilágyi) 
Kata Szilágyi - Anette Sand-Eriksen • Medieval Norwegian Wooden (Stave) Churches

fortification in Fyrkat, the historical town of Jelling and and Framlev church, the Flatatunga boards from the Hólar Cathedral in Iceland, as well as the 8th-11th century trading settlement Hedeby (Haithabu) in Germany (Hauglid 1970, 117-144) (Fig. 7).

\section{ORNAMENTAL ELEMENTS AND PORTALS}

There are many carvings of deities, people and objects from Nordic mythology on these buildings. Some of these carvings could have functioned as defensive spells or apotropaic elements. They were often placed at the edges of the gable roofs. Other frequently carved elements are the cross and depictions of dragons, especially the stylized dragonheads, but also serpents and other monsters occur. The crosses were probably mostly intended as an effective defence against natural spirits, and less as a symbol of the new religion (ANKER 1997, 265-267). The stylized dragonheads were mostly placed in an east-west direction - same as the movement of the sun. Dragons were considered a demon, and a dragon could only be tamed by its own image. The same type of dragonheads was also depicted on Viking ships, but here they served as a magical act, transforming the ship into a monster equally strong as the dragon, thus arming the Vikings against their enemies.

Carvings also occur on other, interior parts of the stave churches. One example is the bishop's chair in Heddal, showing a scene from the legend of Sigurd the dragon slayer. This is believed to have functioned as a link between pagan tales and Christian teachings. Ornamentation in stave churches is, however, mostly known from the around 120 preserved portals, most of which originates from destroyed church (ANKER 1997, 225). One example is Hylestad Stave Church (ID: C4321) (AnKer 1997, 253-256; Universitetsmuseet 2020), dated to the second half of the 12th century and destroyed in 1838 . Today, the portal is exhibited in the Museum of Cultural History in Oslo (Fig. 8), and, just as the bishop's chair, the portal shows scenes

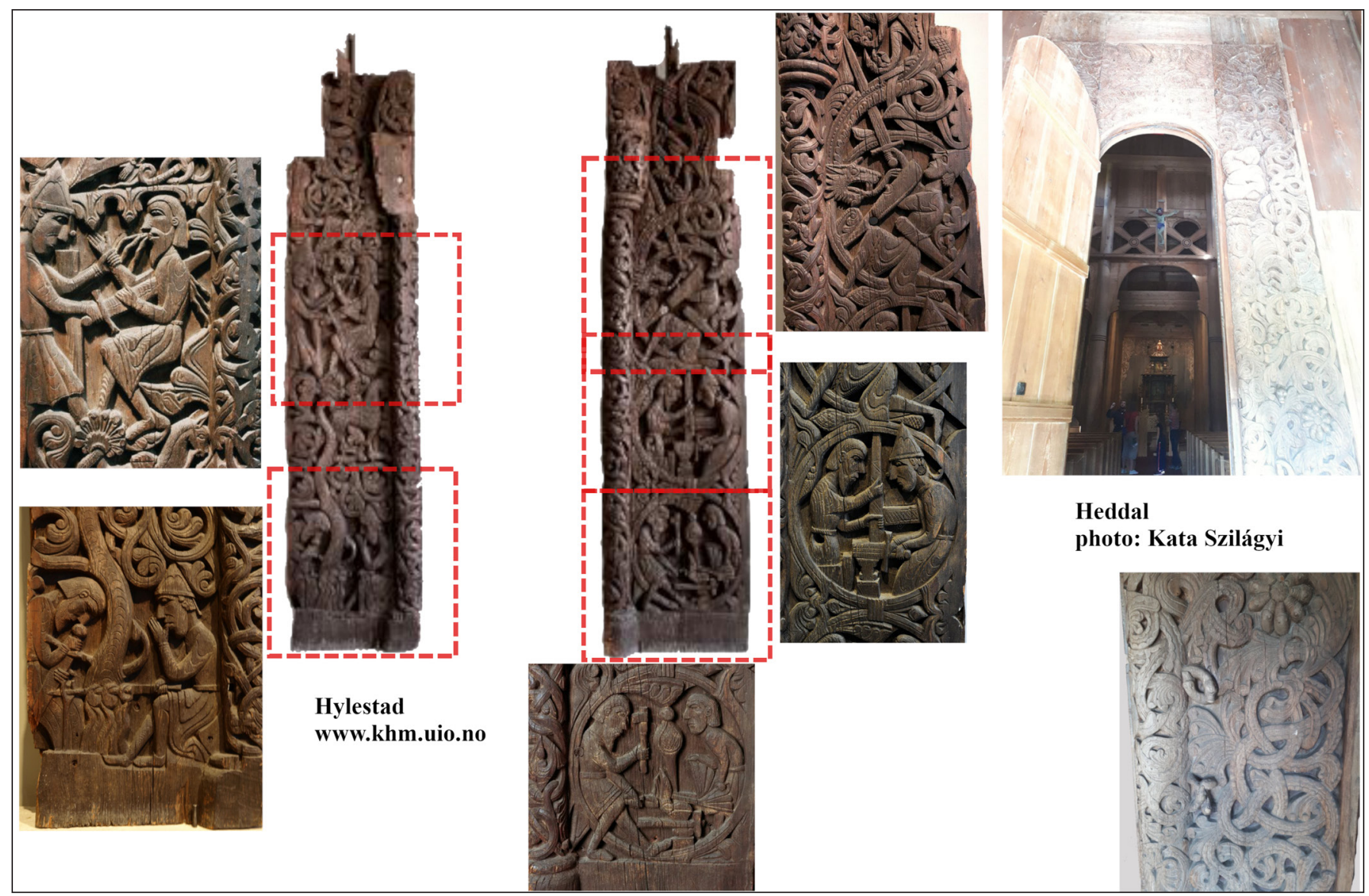

Fig. 8. Portals from Hylestad and Heddal (Photo of Hylestad@ University of Oslo, photographer: Ove Holst, source: Universitetet i Oslo, Kulturhistorisk Museum, https://www.khm.uio.no/) 
Kata Szilágyi-Anette Sand-Eriksen • Medieval Norwegian Wooden (Stave) Churches

from the legend of Sigurd. The portal's excellent artistic quality and design display a high level of skill and labour. Most of these designs refer to the concept of 'liminality', the metaphorical connotation and daily experience of crossing a threshold. The threshold may refer to the concept of heaven, leaving the 'mundane' world to enter a 'sacred' place (FALKENBURG 2019, 20-24).

\section{CRAFTSMEN}

The knowledge of building stave churches was transferred from one region to another. In this process the craftsman, the skilled craft carpenter, was the key person, who had to combine local conditions and materials with the vernacular way of building stave churches. This meant that the craftsman had to find appropriate solutions for the local economic conditions and combine it with the practical need and the religious role of the parish, as well as taking topography, climate, materials, and aesthetics of the local architectural tradition into consideration. As a result, both the distinct signature of the individual master builder as well as the local community's collective cultural memory (which could be the memory of religious, political and minor social groups) had an impact on the final appearance of the church. The master builder's signature makes it possible to detect the person behind the stave churches across space. The many similarities between, for example, Gol, Hegge, and Borgund Stave Church (ANKER 1997, 139), might indicate that the churches were built by the same craftsmen (ANKER 1997).

The craftsmen, as master builders, could be the leaders of a corporation/workshop of workers, in addition to unskilled manual labourers. The latter where most likely hired locally, while the former could be travelling individuals or groups of carpenters, or they might have been members of an association or some craft organisation (HaUgland \& Dolven 2021). Transfer of knowledge must have had two types: (1) Norwegian craftsmen visiting building sites in other regions (and bringing experience and new ideas back home), or (2) hiring of craftsmen from outside of Norway (thus importing the knowledge about architectural practices from the outside). In the 12th and 13th century it was a flourishing tradition that craftsmen (masters and apprentices) and merchants were organised in associations, which had economic and political power at the end of the Middle Ages in Northern Europe. In the case of stave churches, one can also argue that the craftsmen were instrumental in the preservation and mediation of collective cultural memories through the appearance of the stave churches (ASSMANN 2008, 110-112).

\section{THE IMPORTANCE OF MEMORY}

In addition to the craftsman's impact on the visual appearance, a range of spatial and social capabilities, such as local topography, closeness to water, group size, and the dominant religion of the local population, were probably taken into account. The specific place chosen for building a church could have a direct connection to ancestors, the land, the local landscape, or it may have been a protected, prominent, clearly visible place, favourable for construction. This could also be manifested through the chosen materials, i.e., where the suitable timber was from. The material itself was often prepared for many years prior to the construction. This preparation consisted of cutting off branches so that the tree would bleed. This meant that resin was retracted into the cells of the tree, henceforth creating heartwood and making the timber resistant to rot and decay. This type of pinewood, called ore-pine, was especially valued in the Nordic world (FALKENBURG 2019, 11).

From a social perspective, the church was a gathering place, where the practice of religion and repetitive ritual activities gave the building a specific set of meanings. One example is funerary ceremony, which was constantly organised around the stave church, and then the churches were defined and regulated as permanent places of funerals by ecclesiastical authorities, which also created durable bonds between the communities and the specific landscape. After 800 years, both Urnes and Heddal Stave Church are still used for funerary services and their immediate surroundings as burial yards. The latter, which is also the largest of all the preserved churches, is still a functioning parish church used for services, baptisms, confirmations, weddings and funerals (Fig. 9). 
Kata Szilágyi-Anette Sand-Eriksen • Medieval Norwegian Wooden (Stave) Churches

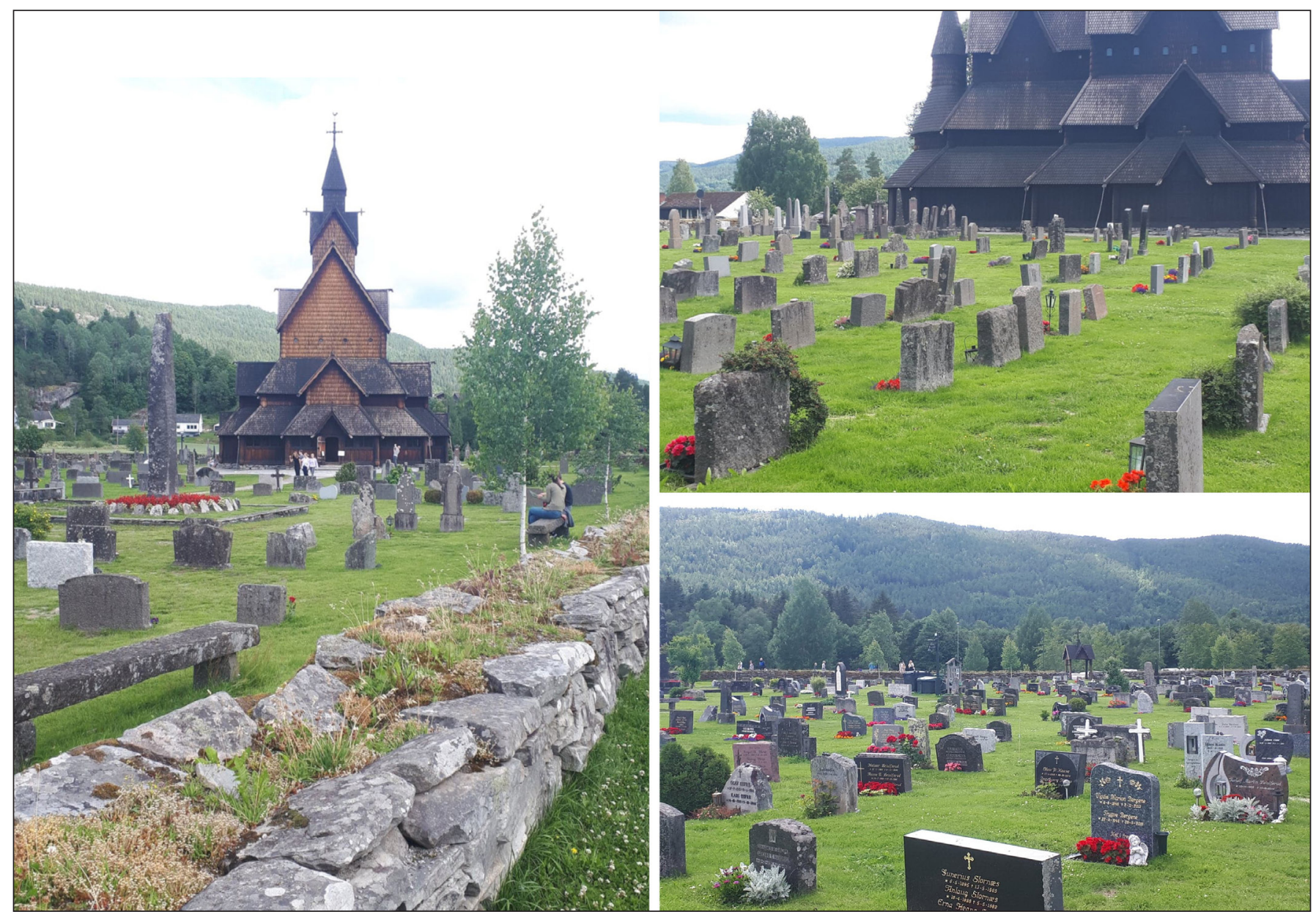

Fig. 9. The recently used cemetery around the Heddal stave church (photo by Kata Szilágyi)

By now, stave churches have become 'transmitting objects' that expand the initial ideological message of Christianisation and its claim to universality. Furthermore, the churches' unique architecture and special location makes them so spectacular that they act as a medium for storing and communicating cultural memories. In order to be able to create a religious building, one needs to make explicit what is the core of the church concept, and then implement it as an architectural form (Assmann 2008, 109-113).

In this cognitive process, one of the key persons is the craftsman - the one able to combine the local material and the vernacular way of building. In this matter, building a stave church was so much more than creating an object, is was a manifestation of both architectural traditions and cosmological concepts. Therefore, stave churches are wooden building inhabiting a sort of visual language and a cultural heritage, that is both unique and a common at the same time.

\section{ACKNOWLEDGEMENTS}

We would like to thank the editors of Hungarian Archaeology, especially Dr. József Laszlovszky, for their valuable comments on the manuscript. The Norwegian residence and prehistoric archaeological research of Kata Szilágyi was supported by the Hungarian National Eötvös Scholarship "Raw material and information flow from social archaeological perspective in Central and North Europe in the 7th-3rd Millenium BC" (MAEÖ 2020-2021/159019) postdoctoral scholarship.

BIBLIOGRAPHY

Ahrens, C. (1982). Frühe Holzkirchen im Nördlichen Europa. Hamburg: Helms Museum. 
Kata Szilágyi-Anette Sand-Eriksen • Medieval Norwegian Wooden (Stave) Churches

Ahrens, C. (2001). Die frühen Holzkirchen Europas. Stuttgart: Theiss.

Anker, L. (2005). The Norwegian Stave Churches. Oslo: ARFO.

Anker, P. (1997). Stavkirkene: deres egenart og historie [The wooden churches: their character and history]. Oslo: Cappelen.

Assmann, J. (2008). Communicative and Cultural Memory. In A. Erll \& A. Nünning (eds.), Cultural Memory Studies. An International and Interdisciplinary Handbook (pp. 109-118). Berlin, New York: Gruyter.

Bampi, M., Buzzoni, M., Haugen, O.E., Meregalli, A. \& Panieri, L. (2018). Le lingue nordiche nel medioevo. Vol. 1: Testi. Oslo: Novus Press.

Berend, N., Laszlovszky, J. \& Szakács, B. Zs. (2007). The kingdom of Hungary. In N. Berend (ed.), Christianization and the Rise of Christian Monarchy: Scandinavia, Central Europe and Rus' c. 900-120 (pp. 319-368). Cambridge: Cambridge University Press.

Bjerknes, K. \& Lidén, H. E. (1975). The Stave Churches of Kaupanger. Oslo: Fabritius Forlag.

Christie, H. (1981). Stavkirkene - arkitektur [Wooden churches: architecture]. In K. Berg (ed.) Norges Kunsthistorie 1: Fra Oseberg til Borgund (pp. 139-252). Oslo: Gyldendal Norsk Forlag.

Falkenburg, J. (2019). Looking Through Portals. An investigation of stave church portals as display objects in Norwegian museums. Oslo: University of Oslo.

Flintoe, J. (1834). Samlinger til det Norske Folks Sprog og Historie [A collection on the language and history of the Norwegian people]. Christiania.

Haugland, H. \& Dolven, A. S. (2021). Laug i Europa [Associations in Europe]. In E. Bolstad (ed.), Store Norske Lexikon. https://snl.no/laug Accessed: 25.02.2021.

Hauglid, R. (1970). Norwegische Stabkirchen. Oslo: Dreyer.

Hoftun, O. (2008). Kristningsprosessens og herskermaktens ikonografi $i$ nordisk middelalder [The iconography of baptism and royal power in the Nordic countries in the Middle Ages]. Oslo: Solum.

Hohler, E. B. (1981). Stavkirkene. Den dekorative skurd [Wooden churches: ornamental carvings]. In K. Berg (ed.) Norges Kunsthistorie 1: Fra Oseberg til Borgund (pp. 253-355). Oslo: Gyldendal Norsk Forlag.

Jensenius, J. H. (1988). Lomen Stavkirke: en matematisk analyse [The wooden church in Lomen: a mathematical analysis]. Riksantikvarens Skrifter Nr. 5. Oslo: Avheim \& Eide.

Jensenius, J. H. (2000). Research in medieval, Norwegian Wooden Churches. Relevance of Available Sources. Nordic Journal of Architectural Research 13 (4), 7-23.

Jensenius, J. H. (2017). Stavkirke Info Information on wooden churches. https://stavkirke.info/Accessed: 27.10.2020.

Stavkyrkjeeigarforum (2020). Stavkyrkjene - Noreg sitt bidrag til verdsarkitekturen [The wooden churches: Norway's contribution to the world's architecture]. https://stavechurch.com Accessed: 27.10.2020. 
Kata Szilágyi-Anette Sand-Eriksen • Medieval Norwegian Wooden (Stave) Churches

Tschudi-Madsen, S. (2019). Stavkirke [Wooden church]. In E. Bolstad (ed.), Store Norske Lexikon. https:// snl.no/stavkirke Accessed: 27.10.2020.

Universitetsmuseet (2020). Universitetsmuseenes IT-organisasjon MUSIT. https://unimus.no Accessed: 19.11.2020.

Valebrokk, E. (1993). Norwegische Stabkirchen: Architektur, Geschichte und Traditionen. Oslo: Boksenteret.

Wikipedia (2020). Vang Stave Church. https://en.wikipedia.org/wiki/Vang_Stave_Church Accessed: 20.12.2020. 